\title{
In vitro CULTURE OF Spondias mombin L. NODAL SEGMENTS ${ }^{1}$
}

\author{
CRISTINA PAIVA DA SILVEIRA CARVALHO ${ }^{2}$, DIVA CORREIA³, ABDELLATIF KEMALEDDINE BENBADIS ${ }^{4}$, \\ JOSÉ MAGNO QUEIROZ LUZ 5 , ADROALDO GUIMARÃES ROSSETTI ${ }^{6}$
}

\begin{abstract}
Spondias mombin L. shoot cultures were initiated from nodal explants taken from plants propagated by seeds. Explants coming from 4-6 months old plants, previously disinfected, were cultivated on WPM medium supplemented with a wide range of concentrations of BAP (0.0, 0.22, $0.44,2.22$ and $4.44 \mu \mathrm{M})$ and NAA $(0.0,0.27$ and $2.70 \mu \mathrm{M})$. After four weeks, the responses obtained were axillary shoot and root formation. The first response were preferentially induced with the medium containing only BAP, regardless of the BAP concentration. The addition of NAA on medium reduced significantly axillary shoot formation and induced rhizogenesis. Roots were formed on nodal explant basis, preferentially on medium supplemented with $4.44 \mu \mathrm{M}$ NAA. The medium supplemented with BAP reduced significantly root formation.
\end{abstract}

Index Terms: Anacardiaceae, hog plum tree, axillary shoots.

\section{CULTURA in vitro DE SEGMENTOS NODAIS DE Spondias mombin L.}

RESUMO - Cultura de brotos de Spondias mombin L. foram iniciadas a partir de explantes nodais retirados de plantas propagadas por sementes. Explantes provenientes de plantas com 4 a 6 meses após a germinação e previamente desinfestados foram cultivados em meio WPM suplementado com uma ampla variedade de concentrações de $\operatorname{BAP}(0 ; 0,22 ; 0,44 ; 2,22$ e 4,44 $\mu \mathrm{M})$ e ANA $(0,0,27$ e 2,70 $\mu \mathrm{M})$. Após quatro semanas, as respostas obtidas foram a formação de brotos axilares e raízes. A primeira resposta foi preferencialmente induzida com meio contendo apenas BAP, independentemente da sua concentração. A adição de ANA no the meio reduziu significativamente a formação de brotos axilares e induziu rizogênese. Raízes foram formadas na base dos explantes nodais, preferencialmente em meio suplementado com 4,44 $\mu \mathrm{M}$ de ANA. Meio suplementado com BAP reduziu a formação de raízes significativamente.

Termos para indexação: Anacardiaceae, cajazeira, brotos axilares.

Hog plum tree (Spondias mombin L.) is a deciduous fruit species widely spread in tropical America (Leon \& Shaw, 1990). This species is evaluated for its fruit as an unconventional source of vitamin A and $\mathrm{C}$, that are used for making juices, ice-creams and jellies (Keshinro, 1985). This plant has also a medical importance. Its leaves contain antiviral ellagitannins and caffeoyl esters (Corthout et al., 1991 and 1992) and leaf extracts presents antibiotic action (Ajao et al., 1985)

S. mombin is traditionally seed propagated (Arkcoll, 1990). However, as result of low germination rate of hog plum seeds, the propagation by sexual method is not applied to large scale production in this species (Sousa and Araújo, 1999). Other problem related to hog plum seed propagation is the high genetic variability among populations (Adler and Kielpinski, 2000).

Vegetative propagation by stem cuttings has not been satisfactory for this species. Propagation using root suckers is possible, but it is slow time-consuming and provides only limited number of propagules (Hartmann et al., 1990). Since conventional asexual methods have been unsuccessful, hog plum commercial orchards have not been established yet (Sousa and Araújo, 1999).

In spite of the economic importance of Spondias mombin, there have not been reports about in vitro culture of this species. For another species of genus Spondias ( $S$. tuberosa), in vitro culture has been attempted but with limited success (Oliveira, 1989). This communication deals with establishment of favorable conditions to induce axillary shoot formation and rhizogenesis from nodal segments of S. mombin.

Seeds of Spondias mombin were collected from native trees located on Northeast region of Brazil and sown in beds containing sand : humus (2:1). Shoot tips with 3-8 nodes were obtained from 4 to 6 month old seedlings. After removing the leaves, the shoots were thoroughly washed in running water and disinfected previously in etilic alcohol $(70 \% \mathrm{v} / \mathrm{v})$ for $1 \mathrm{~min}$. Afterwards, segments were sterilized in a mixture of $0.02 \%(\mathrm{w} / \mathrm{v})$ mercuric chloride with Tween 20 (2 drops/ $100 \mathrm{ml})$ for $10 \mathrm{~min}$. and rinsed three times in sterile distilled water.

Each nodal segment were cut to $1.0 \mathrm{~cm}$ long and placed in vitro on WPM medium (Lloyd and McCown, 1980) with $2.0 \%$ sucrose. The medium were gelled with $0.7 \%$ agar. The $\mathrm{pH}$ of the medium was adjusted to 5.6 before autoclaving at $121^{\circ} \mathrm{C}$ for $15 \mathrm{~min}$. The explants were placed in test tubes containing $10 \mathrm{ml}$ of the medium supplemented with NAA ( 0 , 0.27 and $2.70 \mu \mathrm{M})$ and $\mathrm{BAP}(0,0.22,0.44,2.22$ and $4.44 \mu \mathrm{M})$, singly or in combination. The experiment was established in random outline and was repeated three times with 15 replications per treatment.

The cultures were maintained at an average of $26 \pm 1^{\circ} \mathrm{C}$, with 12 : $12 \mathrm{~h}$ (light : darkness) photoperiod, provided by cool white daylight fluorescent lamps. In the first week, the cultures were maintained under luminous intensity of approximately 200 lux. In the three subsequent weeks the luminous intensity were of 1000 lux.

Analysis of variance and regression analysis by orthogonal polynomial was employed to verify trend and relationship between variables. The number of explants inducing shoots and the length of shoots were recorded after 4 weeks in vitro.

Nodal segments cultivated on WPM medium containing different concentrations of BAP revealed shoot induction after 2 weeks of culture. Explants cultivated on growth-regulator-free-agar-gelled medium also induced shoots. Although variance analysis (Table 1) have showed that all tested BAP concentrations $(0.0,0.22,0.44,2.22$ and $4.44 \mu \mathrm{M})$ were not significantly different $\quad(\mathrm{p}<0.05)$, high percentages of explants with axillary shoots (86.6 to 95.5\%) were obtained after four weeks from culture initiation. In fact, regression analysis showed that BAP concentration did not contribute with the increase of shoot formation average. Thereafter, the application of the highest concentration of BAP (4.44 $\mu \mathrm{M})$ did not result on shoot improvement.

The number of explants inducing shoots was significantly reduced or even inhibited by addition of NAA $(0.27 \mu \mathrm{M}$ and $2.70 \mu \mathrm{M})$ on the medium, whether BAP was present on the medium or not. ANOVA showed that auxin concentrations $(\mathrm{p}<0.01)$ influenced significantly shoot formation (Table 1). From regression analysis, quadratic relation between NAA concentration and shoot induction was observed (Table 1). However this relationship is inverse. In fact, nodal segments cultured on WPM medium without NAA showed maximum response of shoot induction, while addition of NAA $(0.27$ and $2.70 \mu \mathrm{M})$ reduced significantly

1 (Trabalho 142/2001). Recebido: 01/09/2001. Aceito para publicação: 21/08/2002.

2 Bióloga, Mestre em Agronomia/Fitotecnia; UFC, Campus Pici, Av. Mister Hull, s/n, CEP 60020-181, Fortaleza - CE

3 Bióloga, Mestre. Pesquisadora da Embrapa Agroindústria Tropical. Rua Dra. Sara Mesquita, 2270, Planalto do Pici. CEP 60511-110, Fortaleza - CE. diva@cnpat.embrapa.br;

4 Doutor. Professor Visitante do Depto. De Fitotecnia/UFC, Campus do Pici. Av. Mister Hull, s/n CEP 60020-181, Fortaleza - CE.

5 Engenheiro Agrônomo, Doutor. Prof. do Departamento de Agronomia, UFU, Campus Umuarana.

6 Matemático, Mestre. Pesquisador da Embrapa Agroindústria Tropical. Rua Dra. Sara Mesquita, 2270, Planalto do Pici, CEP 60511-110, Fortaleza - CE.i

Rev. Bras. Frutic., Jaboticabal - SP, v. 24, n. 3, p. 776-777, Dezembro 2002 
the average of explants inducing shoots.

Significant interaction (ANOVA) of BAP and NAA was not observed on shoot formation, indicating that there is no dependence relationship between those factors.

In general shoots obtained in vitro hit a short length.

The longest shoots $(8.1 \mathrm{~mm})$ were observed when explants were cultivated on WPM medium supplemented with $0.22 \mu \mathrm{M}$ BAP. Shoot length was reduced in explants cultivated on medium supplemented with NAA, apart from BAP concentrations. Reductions of shoot length was mostly observed on medium supplemented with $2.70 \mu \mathrm{M}$ NAA .

Each shoot originated from nodal explants displayed 5.1 to 6.2 new nodes. However buds of shoots formed in vitro were not able to emit new shoots.

Table 1 - Variance and regression analyses for the variables shoot and root induction from explants of Spondias mombin cultivated for four weeks on WPM medium supplemented with NAA and BAP.

\begin{tabular}{lccccc}
\hline \multicolumn{1}{c}{ Source of variation } & Df $(\mathbf{n}-\mathbf{1})$ & \multicolumn{2}{c}{ AS } & \multicolumn{2}{c}{ R } \\
\hline & & MS & F & MS & F \\
\hline NAA & 2 & 594.60 & $217.54^{* *}$ & 1.74 & $21.89^{* *}$ \\
BAP & 4 & 5.53 & $2.02^{\text {ns }}$ & 0.51 & $6.42 * *$ \\
Interaction (NAA x BAP) & 8 & 1.93 & $0.71^{\text {ns }}$ & 0.37 & $4.75^{* *}$ \\
Error & 30 & 2.73 & - & 2.39 & - \\
Corrected total & 44 & - & - & - & - \\
NAA linear regression & 1 & 1150.03 & $420.74^{* *}$ & 0.43 & 5.46 \\
NAA quadratic regression & 1 & 39.17 & $14.33^{* *}$ & 3.05 & $38.32 * *$ \\
BAP linear regression & 1 & 6.76 & 2.47 & 0.04 & 0.47 \\
BAP quadratic regression & 1 & 1.34 & 0.49 & 1.05 & 13.68 \\
BAP cubic regression & 1 & 12.31 & 4.50 & 0.32 & 4.02 \\
BAP 4 ${ }^{\circ}$. grade regression & 1 & 1.72 & 0.63 & 0.64 & $8.01 *$ \\
NAA linear x BAP linear & 1 & 0.02 & 0.01 & 0.09 & 1.17 \\
NAA linear x BAP quadratic & 1 & 0.43 & 0.16 & 0.19 & 2.36 \\
NAA linear x BAP cubic & 1 & 1.94 & 0.71 & 0.0 & 0.01 \\
NAA linear x BAP 4 ${ }^{\circ}$. grade & 1 & 0.18 & 0.07 & 0.09 & 1.17 \\
NAA quadratic x BAP linear & 1 & 8.03 & 2.94 & 0.15 & 1.84 \\
NAA quadr. x BAP quadr. & 1 & 0.31 & 0.11 & 1.42 & $17.85 * *$ \\
NAA quadr. x BAP cubic & 1 & 3.11 & 1.14 & 0.26 & 3.24 \\
NAA quadr. x BAP 4 ${ }^{\circ}$.grade & 1 & 1.44 & 0.53 & 0.82 & $10.32 * *$ \\
\hline
\end{tabular}

$\mathrm{ns}=$ not significant $* *=$ significant at $\mathrm{p}=0.01 ; *$ significant at $\mathrm{p}=0.05$

$\mathrm{R}=$ roots; $\mathrm{AS}=$ axillary shoots

Roots were formed in explant basis after two weeks from culture initiation. ANOVA showed that both NAA and BAP interfered significantly $(\mathrm{p}<0.01)$ in root formation. NAA effect over root formation was positive. In fact, the highest percentage of root formation $(33.3 \%)$ were achieved on medium supplemented with $2.70 \mu \mathrm{M}$ NAA. Root formation was observed on medium supplemented with only $0.27 \mu \mathrm{M}$. On medium without auxin, root induction was not observed.

The BAP effect over root formation was negative. Medium supplemented with BAP mainly with higher concentrations (2.22 and $4.44 \mu \mathrm{M})$ were not favorable to root induction. The interaction between NAA and BAP was also significant $(\mathrm{p}<0.01)$. Then, cytokinin application to culture medium acted minimizing auxin effect over root induction from nodal explants.

Regression analysis confirmed the significant action of NAA and BAP over root formation, indicating that for the two factors, the quadratic regression was significant $(\mathrm{p}<0.01)$. The significant interaction between NAA and BAP was also confirmed by regression analysis (Table 1). In the culture of $S$. mombin the root formed at explant basis were variable in number, shape and length. Most of roots formed were associated to callus.

\section{REFERENCES}

ADLER, G. H.; KILPINSKI, K. A. Reproductive phenology of a tropical canopy tree, Spondias mombin. Biotropica, Leawrence, v.32, n.4, p. 686-692, 2000.

AJAO, A. O.; SHONUKAN, O. O.; FEMI-ONDEKO, B. Antibacterial effect of aqueous and alcohol extracts of Spondias mombin and Alchornea cordifolia: Two local antimicrobial remedies. International Journal of Crude Drug Research, Leisse, v.23, n. 2, p. 67-72, 1985.

ARKCOLL, D. New Crops from Brazil. In. JANICE, J.; SIMON, J.E. Advances in new Crops, Ed., 1990. p. 367-373

CORTHOUT, J.; PIETERS L. A.; CLAEYS, M.; VANDENBERGHE, D. A.; VLIETINCK, A. J. Antiviral ellagitannins from Spondias mombin. Phytochemistry, Oxoford, v.30, n.4, p. 1129-1130, 1991.

CORTHOUT, J.; PIETERS, L. A.; CLAEYS, M.; VANDENBERGHE, D. A.; VLIETINCK, A. J. Antiviral caffeoyl esters from Spondias mombin. Phytochemistry, Oxoford, v.31, n.6, p. 1979-1981, 1992.

HARTMANN, H. T.; KESTER, D. E.; DAVIES, J. F. T. Techniques of propagation by cutting: plant propagation principles and practices. Ed. Prentice-Hall International, 1990 p.256-304.

KESHINRO, O. O. The unconventional sources of ascorbic acid in the tropics. Nutrition Reports International, Stoneham, v.31, n.2, p.381387, 1985.

LEON, I.; SHAW, P. E. Spondias: The red mombin and related fruits. In. NAGY, S.; SHAW, P. E.; WARDOWSKI, W. F. Fruits of tropical and subtropical origin - Composition, Properties and Uses, editora, 1990, p.116-126.

LLOYD, G. B.; McCOWN, B. H. Commercially feasible micropropagation of mountain laurel Kalmia latifolia by use of shoot tip culture. Proceedings International of Plant Propagation v. 30, p.421-427, 1980.

OLIVEIRA, C. S.; SATO, A.; ESQUIBEL, M. A.; OLIVEIRA, V. R. Propagação de Spondias tuberosa Arr. (umbu) através de cultura de tecidos. Horticultura Brasileira, v.7, n.1, p.69, 1989.

SOUZA, F. X.; ARAÚJO, C. A. T. Avaliação dos métodos de propagação de algumas Spondias agroindustriais. Fortaleza: EmbrapaCNPAT, 1999. p. 1-4 (Comunicado técnico, 31) 